\title{
People who move and need news \\ The economic and social value of providing digital journalism services for mobile and remote audiences
}

\author{
John Cokley \\ Swinburne University of Technology \\ Margie Comrie \\ Massey University
}

\section{Summary}

This article proposes historical precedents for policies which support journalism enterprises that serve populations 'on the move' using communications networks and technologies. A contemporary case study is used to support an economic argument that there is a rationale for continued governmental intervention in journalism in the sphere of the international and domestic movement of passengers, cargo and discrete groups of linked individuals. It concludes that this sphere represents a valuable productivity opportunity for Australia which the Federal Government should exploit.

\section{Introduction}

Journalists and news publishers have spent the past 15 years chasing audiences down rabbit holes. Where once audiences were to be found in clearly defined groups and locations, disruptive technologies - most recently, mobile devices and applications - have been viewed as splintering these audiences into smaller and smaller groups (Thorn 2009, 431), disappearing down narrower and narrower holes. The most mobile so far, the iPhone and other 'smart phones', have reduced this granularity to singularity and made the news consumption experience appear to be an individual one, not a communal one.

This article reports on a rare but promising instance in which the rabbit hole has become a looking glass, and in which the singularising effects of mobile digital technologies have been used to identify and cultivate larger more viable communities of news consumers, which can then ironically be reassigned New York University's Professor Jay Rosen's epithet 'the people formerly known as the audience' (Rosen 2006, n.p.).

Based on this instance, we revisit historical data about how government support for media enterprises in the $18^{\text {th }}$ to $20^{\text {th }}$ centuries was effective in promoting sustainable communities and productive media enterprises in the United States, Australia and the United Kingdom, to 
suggest a policy initiative relevant to Australia's National Broadband Network and its international equivalents.

\section{The role of subsidy in news distribution}

Early postal services helped the development of emerging news media in England (Milne 2010, 49) and North America (Kielbowicz 2009, 399) and news transmission accelerated at the same speed as the technology used to transmit it. Post began developing in England in the $16^{\text {th }}$ century, and in 1591 the proclamation of a state postal monopoly established the post office as the major player in written communications (Milne 2010, 30). Mail was carried on foot, then on horseback and accelerated with a spurt in the $18^{\text {th }}$ century: the English mail coach was introduced in 1784, rail transport of mail commenced in 1830, the electrical telegraph arrived in 1837 and the English 'Penny Post' was instituted in 1840 (Milne 2010, 29-43).

Traffic was not all one-way. Two-way communication channels have been vital to the development of journalism, and postal delivery services have also been central to those channels. From a US journalist and publisher's point of view, 'the Post Office performed two services indispensable to newspapers as they developed through the nineteenth century: it aided editors' newsgathering efforts, and it carried publications from print shops to readers' (Kielbowicz 2009, 399). At this early point in journalism's history, the idea of government support for news businesses began to gather support.

This support was evident in the United States Post Office Acts of 1792, 1845 and 1879. The 1792 Act privileged carriage and delivery of newspapers over letters to the extent that a newspaper of any size or weight could be posted anywhere in the country for $1 \frac{1 / 2}{2}$ cents while a letter of similar size and weight could cost up to 75 cents postage: 'Public papers will be expeditious messengers of intelligence to the most remote inhabitants of the Union', wrote Secretary of the Treasury Alexander Hamilton at the time (Kielbowicz 2009, 399). Editors were even able to exchange newspapers among themselves post-free, a precursor to the modern press associations and news agencies (Kielbowicz 2009, 399). The 1845 Act introduced the concept of free postage for weekly newspapers within 30 miles of the office of publication (later amended to apply to the county of publication). The 1879 Act (incorporating the Mail Classification Act) created a mail classification which endured until the 1990s: first class for letters, second class for periodicals, third class for advertising, and fourth class for parcels (Kielbowicz 2009, 400). At this stage, conditions began to be applied to what kind of publication attracted the second-class discounted postal rate.

To qualify for the second class, a publication had to (1) appear at regular intervals at least four times a year: (2) come from a known office of 
publication; (3) consist of printed sheets without substantial binding; and (4) disseminate 'information of a public character, or be devoted to literature, the sciences, arts, or some special industry, and having a legitimate list of subscribers (Kielbowicz 2009, 400).

Excluded were publications 'designed primarily for advertising purposes, or for free circulation, or for circulation at nominal rates' (Kielbowicz 2009, 400). This second-class postage was reduced even further (halved) to 1 cent per pound ('a penny per pound') of paper in 1885 .

Earlier, Kielbowicz $(1984,1)$ had identified a link between the historical development of US postal services and technology and the development of newspapers - and even the development of social structures in the $19^{\text {th }}$ century: 'three factors affected the quantity of news that circulated through the mails: the speed of delivery, the patterns of circulation, and the form in which the information appeared'. He concludes that:

... born partly of the colonial post office, the American newspaper grew into a complementary agency of communication that specialised in gathering and processing information (and) the very centrality of the post office and the press in 19th century life drew them into debates about the proper role of federal enterprise (and) the relation of national to international interests (Kielbowicz 1984, 179).

This approach reflected the general political and commercial belief of the time that subsidies which assisted the distribution of journalism-based publications amounted to good policy. President George Washington would have preferred that newspapers and other periodicals travel entirely free of charge (United States Postal Service 2010, n.p.). However, economics pushed in the other direction and the 'penny per pound' rate was diluted after World War I to 1.254 in 1918 and $1.5 \$$ in 1921 (United States Postal Service 2010) thus effectively reducing the subsidy. By the 1950s, politicians had begun to complain even more loudly. In February 1951, in a special message to Congress, President Harry S. Truman argued at length for a rate increase:

In fiscal year 1952 ... newspaper and magazine publishers will have 200 million dollars - or 80 percent - of their postal costs paid for them by the general public ...These rates were intentionally set low, when they were established, in order to encourage the spread of information and education among our citizens. This is still a desirable object, but clearly does not warrant a subsidy as extreme as that which now exists ... (United States Postal Service 2010) 
The dilution of postal subsidy continued, and by 1988 the 'regular per-pound rate for periodicals' had risen to $12.4 \$$, which - considering movements in the US consumer price index $^{\mathrm{i}}$ - was equivalent to $2 \phi$ in 1918, effectively a 50\% reduction in support. By 2009 , however, when Congress announced that it would require 'market-dominant types of mail, which included periodicals, to bear their attributable costs ... (at that time) periodicals covered about 76 percent of their costs - falling short by more than $\$ 600$ million' (United States Postal Service 2010) the 'per pound' had risen to only $18.3 \phi$, equivalent to $1 \phi$ in 1918 , thus effectively reinstating the 'penny-a-pound' regime and doubling the subsidy when compared with 1988. Even more attractive rates remained available for non-profit organisations and for 'classroom publications'. While a deeper analysis of these movements is beyond the scope of this article (residing more in the disciplines of economics and political science) it is noted that subsidies were mostly maintained during liberal (i.e. Democrat) presidencies, that subsidies reached their nadir during the conservative (i.e. Republican) presidency of Ronald Reagan, but have been reset to a modern equivalent of the original 'penny-a-pound' under the Democratic Presidency of Barack Obama.

In Australia, postage subsidies have long applied to periodicals. The rules for inclusion are relatively simple and most publishers have been able to arrange the discount. One of the current authors managed the print publication of a national engineering publication from 1984-88 ii under the rules of Australia's national postal service, Australia Post, and these remain practically similar to this day.

To qualify, a publication 'must be a continuing printed periodical with a fixed title, and be issued at least twice a year'. The registration process in 2013 closely resembles the process he undertook in 1984: a copy of the publication must be attached to the application form, and the publisher must identify the title, the main activity or industry the publication refers to, and nominate a category for the publication from these six: business-to-business, loyalty, catalogue, newsletter, general interest or special interest (Australia Post 2013).

The application also must specify the weight and dimensions of the publication and the name and address of the publisher. The discount was obtained by standardising wrapping and addressing of the publications, pre-sorting the items by postcode regions, and then delivering these pre-sorted bundles of magazines to our local postal delivery centre, not any ordinary post office. The savings were substantial in the 1980s, even considering the extra cost and effort involved in using a sorting and wrapping contractor to fulfil the postal conditions.

Similar discounts for periodicals are available today in Great Britain but the conditions are slightly different and pricing is much more complex. Principally, there are tighter conditions in the UK about what qualifies as a periodical: 
At least one-sixth of the periodical must be editorial content (and) editorial content does not include advertising material or data or any information relating to a product or service such as pricing information or product descriptions, which relate to either the publisher of the magazine, the owner of the magazine or a third party (Royal Mail 2013a).

The frequency requirements are similar (it must be published and posted using the Royal Mail Publishing service at least twice a year) and the front cover must clearly show its title and either the issue date, the month, the season or the issue number. There are quantity and pre-sorting requirements to achieve a range of discounts, which vary from 0.5 percent to 4 percent. Catalogues, brochures, directories and exhibition guides are not deemed to be magazines, newsletters or journals. And individual items must not weigh more than 750 grams (Royal Mail 2013b). Superficial analysis of the pricing system suggests that while the publisher in 1984 was able to calculate individual and bulk-sorted prices using hard-copy price lists and a calculator, he would need a computerised spreadsheet in 2013 to isolate the correct price given the possible variables published by Royal Mail. This suggests that an ability and willingness to operate and understand the outputs of financial spreadsheets is a useful attribute for journalist/publishers in the small-to-medium sized sector.

\section{Other countries}

There are examples of subsidies for news journalism enterprises in other countries. This article does not pretend to name them all, but Picard $(1985,3)$ presents a comprehensive table of financial interventions by nations to assist media organisations, covering, among other forms of support, tax rates, postal rates, telecommunications rates, education and research subsidies, loans and placement of government advertising. Picard notes 16 countries implementing some kind of intervention and 14 of them provided postal delivery subsidies: Austria, Belgium, Canada, Denmark, Finland, France, Germany, Italy, the Netherlands, Norway, Sweden, Switzerland, the United Kingdom and the United States. Among those, all but Canada, the US and the UK also provided telecommunications assistance.

Examples of other kinds of subsidy are provided for comparison. In Austria in 2010 (Fidler \& Föderl-Schmid 2012, 2010) approximately $€ 2.5$ million was provided to support distribution costs of daily and weekly newspapers, €6.6 million was provided to dailies assessed as having special importance for the forming of opinions, and in 2009, €1.6 million was provided to support quality and training initiatives. Sweden is frequently cited as an example of widespread media subsidies and Ots (2009) provides examples of support by the Swedish Press Subsidies Council, especially for news media serving ethic and language minorities 
(Camauër 2003). A new support measure in France in 2009 amounted to $€ 600$ million; in the same year the Netherlands launched a scheme to fully fund two young journalists on each of Holland's 30 daily newspapers for two years and in the US state of Washington, the government allowed a 40 per cent tax break for newspaper printers and publishers (in Macnamara 2010, 29-30).

\section{An Australian contemporary example}

The most recent (at time of writing) contemporary example of government directly subsidising a news media publication which is delivered by email and HTML website occurred in May 2013. The publication was The Conversation, described as 'a not-for-profit company providing independent analysis, commentary and news sourced from the university and research sector and delivered free to the public' (Australian Government 2013) and based at the University of Melbourne. The Australian Government's Federal Budget statement (Australian Government 2013) allocated $\$ 2$ million in cash over two years 'to help support The Conversation' and a further $\$ 1.8$ million over four years by allowing taxdeductible status for The Conversation's managing foundation. The budget papers did not include details of how the cash subsidy might be structured.

While such subsidies are widespread, government intervention in media business is a contested field. Governments have limited budgets and funding for media is decreasing as a result of liberal (marketplace) economic policies, witness the dwindling support for public service broadcasting in Europe, Britain, Canada and Australia. Further, media organisations fear that subsidies may go hand-in-hand with government interference. Existing news publishers in Australia have even campaigned against subsidies (Macnamara 2010, 30).

\section{The issue of sustainability}

Subsidies for news organisations have been granted on the basis that informed communities are healthy and strong communities. While a complete discussion of the merits of this position would be outside the scope of this article, recent examples from East Timor and New Zealand suggest this remains a strong argument nevertheless.

In East Timor, after the disastrous riots of 1999, the withdrawal of news media and the potential reduction in residents' public sphere activity had a destructive effect on communities:

'There is a news vacuum here and rumours thrive because there are no newspapers. Gossip through the grapevine can be damaging to nationbuilding' (Da Silva, in Cokley et al 2000, 28). 
Research into the effects of media deprivation after the Christchurch earthquake in 2011 (Winstanley et al. 2011) also suggests that targeted and focused new media services can add appreciably to preserving and rebuilding social capital after a natural disaster. Mainstream media did not provide residents in the disaster zone with the information they needed, and power outages meant they could make only limited use of mobile technologies such as SMS and social media sites. They relied on local 'information hubs' with whiteboards and simple newsletters. The aftermath report recommends strengthening existing human communication networks and more robust communication support and technology.

\section{Mobility as a form of capital}

One reason for news distribution being credited with enhancing communities - noted in the early United States, in Australia, in Europe and more recently in East Timor and New Zealand - is that effective and professional news distribution enhances social capital within communities. Mobilities research (Flamm \& Kaufmann 2006, 167) suggests that mobilityiii (or being 'on the move') is also 'a form of capital, similar to economic, social or cultural capital, present as a factor in social differentiation that modern sociology cannot disregard'. Some of that capital, specifically between groups which are geographically widely distributed but connected by communications networks, can be expressed as 'network capital' which creates interactions 'of similar importance to face-to-face and everyday computing interaction' (Larsen et al. 2006, 279). More specifically, a significant association has been suggested between increased mobility (trip making/activities undertaken) and reduced risk of social exclusion in both metropolitan and regional settings:

... risk of social exclusion may be reduced by policy and program measures that foster development of social capital, particularly in the metropolitan setting. It is noteworthy that improving mobility itself may be one way to foster development of social capital, giving trip making potentially both direct and indirect roles in reducing risks of exclusion. (Stanley et al. 2011)

Those authors are also able to put a dollar value on the outcomes:

If a particular policy, programme or project initiative facilitates additional trip making by someone at risk of social exclusion, that trip has a value of about \$17 if the person has average household income, or a higher value if their household income is lower (conversely, if their household income is higher than the average from the sample). (Stanley et al. 2012, 3606)

Observations around Australia and internationally strongly suggest that mobility and 'trip making' is more a factor of modern life than it has ever been before and therefore more able to contribute to social capital. Mass migrations driven by climate ('out of Africa'), political 
disruption ('out of Asia Minor') and economic variables ('out of Europe', 'out of central America') have been a central historical feature since antiquity, but air travel for business and pleasure, sea travel for pleasure and for logistics, and mass travel during retirement after professional careers, either in small groups or large convoys ('The Grey Nomads') are new factors which can be discussed. New possibilities including health clubs (Cokley \& Volcic 2009) as well as futuristic realms such as space tourism and space colonisation should also be included since embryonic communities now live for long periods in orbit and larger communities are being seriously planned by the European Space Agency and the National Aeronautics and Space Administration (NASA) in the United States ${ }^{\text {iv }}$. Media enterprises and especially journalism businesses are likely to play a part in these environments because 'news from home' is an aid to social cohesion and sustainability (Cokley et al. 2005; Babidge et al. 2005, Rankin \& Cokley 2006).

Latest figures (Oxera 2013) suggest that satellite-based services for 'people who move' known as geo-services - contribute $\$ 150$ billion to $\$ 270$ billion in revenue to companies and governments globally per year. Using a combination of direct effects, consumer effects and wider economic effects, the report extrapolates the contribution of geo-services, calculating an extra $\$ 113$ billion in gross-value-added products 'suggesting that Geo-services account for roughly 0.2 percent of global gross domestic product' (Oxera 2013, iv). The geo-services sector is estimated to be growing at 30 percent per year globally (Oxera 2013, vi). The report aligns geo-services with savings in travel, agriculture, logistics ( $\$ 10$ billion), fuel consumption, education and emergency services. It suggests a further unquantified figure of increased competition in many markets (Oxera 2013, $v$ ) which include journalism and other kinds of information publishing.

An Australian report by consultants ACIL Tasman, prepared for the Co-operative Research Centre for Spatial Information and ANZLIC, the Spatial Information Council (ACIL Tasman 2008), suggests that what it calls the 'spatial information industry' (which seems to be a subset of the geo-services sector studied by the Oxera report above) contributed $\$ 1.37$ billion to the Australian national accounts in 2006-2007 while industry gross value added around $\$ 682$ million (ACIL Tasman 2008, $x$ ). This, it said, 'contributed to a cumulative gain of between $\$ 6.43$ billion and $\$ 12.57$ billion in Gross Domestic Product (GDP) equivalent to 0.6\% and $1.2 \%$ of GDP respectively', increasing household consumption by up to $\$ 6.87$ billion, increased investment by $\$ 3.69$ billion and increased exports by $\$ 2.3$ billion.

The Australian Government's new Satellite Utilisation Policy released in April 2013 squarely aims Federal budgetary policy to earth observations from space, satellite communications and position, navigation and timing (Commonwealth of Australia 2013). At a stakeholder forum in Melbourne in May attended by one of the authors, earth observation and position, 
navigation and timing were identified as the major economic drivers in this policy but communications, where journalism participates, is at least a major contributor even at Number 3 .

\section{The economic contribution of journalism within geoservices}

A noticeable gap in both reports and in the Satellite Utilisation Policy is any direct mention of the contribution to the global economy of geoservices-integrated journalism, namely journalism services provided specifically for mobile populations using networked communications. The same gap exists in the policy for Australia's new National Broadband Network (NBN), which is tasked only with installing infrastructure to supply fixed broadband services to $100 \%$ of Australians. In the words of the Australian Communications and Media Authority (ACMA) 'Every premises in Australia will have the ability to access the NBN by either a fibre, fixed wireless or satellite connection' (ACMA website 2013), emphasis added). However, as part of its planning strategy, the ACMA has conducted a review into the future spectrum requirements for mobile broadband, and this suggests that:

... mobile broadband services are an economic enabler within society and the provision of these services, technologies and applications in the wider community is in the public interest ... (and) demand for spectrum to support mobile broadband services will increase over time. (ACMA 2011)

The current article aims to address the gap between existing fixed broadband policy and future mobile broadband needs with a relevant case study. The instance investigated in this project, Headland Media $^{v}$, is one in which a profit-motivated news publishing enterprise uses satellite-based communications technologies to connect widely distributed groups of individuals who together exhibit the characteristics of mobility capital, and to deliver specifically journalism content for a fee. This approach by Headland Media is considered noteworthy because of the increased productivity it suggests, including the increased business competitiveness it introduces to the global news market. Other journalism enterprises are also entering this market and so we expect this project to have wider significance.

The communications technologies specifically employed for this task are email by satellite and the Adobe Portable Document Format (PDF) for text documents. PDF is arguably the world's most common file format for Internet communications, apart from HTML. Adobe estimates there are more than 1 billion PDF files in circulation (Adobe 2013), quality assured by the ISO 32000 open standard. Earlier studies (Cokley 2008) have shown that PDF is a common file format for publishing and distributing journalism news products. A defining business characteristic of the format is that PDF transfers the cost of the paper and the ink in 
a previously printed product to the consumer, away from the producer (Mellor, in Cokley $\left.\underline{2008}, 127^{\text {vi }}\right)$.

\section{The study: Headland Media}

Headland Media was formerly known as TEAMtalk and has used Adobe PDF format to transmit regular news bulletins to subscribers around the world, including to ships at sea and to Australian researchers in Antarctica. The company was formed as 'IMC' in Liverpool, UK in 1985 by Bernie Thomas and Tim Whalley. Both men were ex-seafarers and had been Maritime Studies lecturers at Liverpool Polytechnic (Henney 2002)) and conducted government-funded research on use of communications systems and computers by ship crews. This resulted in the development of a ship-to-shore messaging system and, later, a news service for cruise companies including P\&O Cruises and Cunard, using material sourced from Associated Press, the Press Association, Agence France-Presse and Australian Associated Press. Stories were selected by editors who then used computer coding to form collected bulletins in the various languages offered in the service.

More fully known as TEAMtalk Satellite before the most recent name change, the company is based in Liverpool, England. At various times it has had additional offices in Charlotte, Chicago, Glasgow, Fort Lauderdale, Leeds, London, Munich and Stockholm (Henney 2002). TEAMtalk Media Group was taken over in July 2002 by UKBetting Plc then later by the Murdoch-owned BSkyB, and was later consolidated in a management buyout but since 2010 has been acquired by the US KVH Industries, manufacturer of 'solutions that provide global high speed Internet, television and voice services via satellite to mobile users at sea, on land, and in the air' ( $\mathrm{KVH}$ website 2013). Revenue in the six months to June 30, 2002, was reported at $£ 17.5$ million (then $\$ A 49.5$ million) equivalent to $£ 23.4$ million in 2012 taking into account inflation ${ }^{1}$.

The TEAMtalk subscriber list for 2002 included 55 news products daily, in 10 languages. They claimed approximately 85 percent of the world's cruise line companies as clients and also sent news to crew on cargo ships, to some remote hotels and to safari camps in Africa, as well as to the Australian Antarctic stations Mawson, Davis, Casey and Macquarie Island (Henney 2002).

In 2010, one of the present authors visited the headquarters of Headland Media on the seventh floor of Citrus House in Dale Street in central Liverpool, and interviewed two senior company representatives: senior editor Bronwyn Jones and head of content Kate Hart (both, personal communication). Jones was a recent graduate from a journalism college and had been working at Headland for about $2^{1 / 2}$ years. At the time of this interview she was undertaking a PhD at John Moores University in Liverpool. On the other hand, Kate Hart 
had been with the company 25 years in the job: 'I arrived within a couple of years of the start-up'. She had entered the business as a translator: 'There isn't much work for those who study languages - teaching or translating. This is much more interesting for me.'

At the time of this interview, Headland produced 32 so-called 'guest editions' in 13 languages: 'sometimes we have an extra edition (e.g. Korean and Swedish)', said Jones. (At time of writing in 2013, the website noted there were '50 editions of daily news in 10 languages to 180 cruise ships worldwide', suggesting that the exact number and range of editions is dependent on demand.) Jones said there were six so-called 'masthead editions' which were condensed forms of major newspapers produced under licence - e.g. the New York Times Digest. The editors said the team was 'very strong multi-lingual'. Jones speaks Italian, French and English.

Jones: 'Our customers are maritime crew and cruise ship passengers, hotel (guests and staff) and one-off's like Army ... anywhere where people abroad want news of home.'

Headland also produces music and news bulletins in retail stores from a radio studio in Leeds. Such bespoke narrowcasts have been studied in Australia, the US and in flight with airlines (Cokley 2008).

Jones said (in 2010) that Headland employed about 40 editorial staff on a 24-hour shift rotation.

'Basically we are copy editors - not journalists writing new stories. We subscribe to major news agencies both big international ones and ones in the languages/countries of our language clients. We also use some Internet news sources and we will check with the major newspapers of that region for breadth of news on that day, to gauge importance of what we've received over the wires, to double check stories/details etc.

'These days the news websites of the major papers often have links to agency copy also for the latest material - they are not ashamed of doing that because they know that the audience wants the latest - however, some newspapers put more effort into updating than others.

'We don't usually use local reporters on the ground. For a while we found it hard to get news from the Philippines (so) we did have freelance material (from there) but now we use the national news agency there.'

'The newspapers are daily (for both crew and passengers). We bear audience in mind and to a certain extent with the cruise passengers we 
understand that it needs to be upbeat - that they don't want all gloom and doom. However, it naturally depends on the major news of the day.

'The concentration is on the country of those who read it, therefore Britain Today (an 8-pager) as is USA Today.' (Jones 2010)

Jones described a typical edition of Britain Today: It has two major stories (from home - of about 10-12 paragraphs) on the front page plus one third of the page side panel on world news - three stories of 3-par each. The next page carries weather news - international and UK - with a 3-par story below that and three moderate length stories in two columns beside that. Page 3 had a similar layout, including a right-hand column of celebrity news. Page 4 is often a 'softer interest feature (perhaps science)' with a quiz, such as a crossword and Sudoku. A page of financial news follows, including stock market reports and about four finance stories. Sport starts on Page 6 and goes to the back page (Page 8) including football and cricket scoreboards, three or four stories, with one major (10-12 pars) and the others slightly shorter. The lottery results and other sports stories complete Page 8.

The publication masthead (a title image on Page 1) identifies each bulletin as Headland SatNews and in some cases carried the brand of the cruise line. Top-of-page straps on each other page display the words: 'Headland SatNews (Sources: PA, AFP, AP)'.

The US paper also was eight pages but most others were four pages only. The size of each edition was dictated by the number of passengers on each client ship: The bigger papers were for US/UK clients because of the number of US and British cruise passengers. Other editions included New Zealand Today, Australia Today, as well as Today's for Canada, Germany, France and Japan. Headland also published a specialist finance newspaper.

According to Jones:

'It's important that these are A4 (newspapers) and black and white - easy to print out and small files. It's not necessary to be particularly technically savvy. We have a big technical team that deals with technical issues and ... is always on the lookout for opportunities and developments. The software has been created in-house - it is simple to work with and the layout is deliberately simple as this means that it aids having small files. Also it makes it easier to provide the number of editions that are done.' (Jones 2010)

Each edition takes about 90 minutes to compile.

Crew newspapers for merchant ships are published as part of a separate Headland Media service called NewsLink (Hoyt 2013). Production for this takes place in India and the Philippines, supplying 74 daily titles, in English or available in 17 crew languages. 
Headland also maintains a network called 'Crewtoo' which it describes as 'a unique social network for merchant shipping crew, aiming to counter the sense of loneliness sometimes felt by those working hard at sea. It is an online 'community', sharing ideas and opinions by e-mail, internet and a dedicated newspaper' (Headland Media 2013)

\section{Audience feedback}

Kate Hart (2010) noted that Headland Media had received 'little response' from individual audience members because its primary business relationship was with the travel provider, the cruise line or the ship owner. She suggested that individual holidaymakers were receiving the paper only while transient therefore there was little or 'no chance to develop a relationship'. However, Bronwyn Jones noted that when travel providers had contacted them, Headland editors had been 'very responsive to emails requesting certain things because of the service aspect of the papers':

... therefore (we) will put a commodities table into the financial paper because someone requested it in a recent email (and it seemed a good idea) ... that will be done - we do service needs.

Hart noted that the daily bulletins did not include pictures but black-and-white graphics are sometimes included 'where they add to the story':

For a while we did have photographs - as this has become much easier with new technologies. We did a couple per addition, but we eventually stopped it (and it does have advantage of smaller and simpler files). It took up too much time - selecting the photos and fitting them into the layout etc. It was adding to the costs - so in the end we just stopped it. No-one complained or commented. The newspapers continue to be very popular so conclusion is that this is not essential. File size is more important for the merchant ships, not so much for the cruise ships.

Stylistically, the emailed newspapers followed a very conventional inverted pyramid format. Hart says:

'In a 2-page issue you'd get 12 or 13 news stories (and) one of two 'feature' stories - these are the more in-depth ones. We don't do features that begin with lots of description - although more of our source material does this ... Even the celebrity news and show business news tends to be straight news.

The editors provided examples of articles in a Britain Today edition: 'Ozzy Osbourne is to be crowned a "living legend in 2008..." "Keira Knightley was the second-highest paid Hollywood actress last year".' Editors also compared their on-going source content with 
online editions of major newspapers, for example the Manila Times (English language newspaper in Philippines) to make decisions about major stories. However, wire service stories generally picked up news quickly, they said.

\section{Hotels - Good Morning News}

Headland Media provides a service to hotels for guests to read at breakfast. These editions were single-page, single-sided, mostly confined to single-paragraph 'briefs'. The standard layout included three main stories - one across four columns, the others below it across two columns, and then six brief 'world' stories and about 12 stories based on the target country, the site of the hotel, such as Good Morning USA; Good Morning France; Good Morning Deutschland. Sports appeared at the bottom at the right. Hotel clients were served in France, Germany, Spain, Italy, United Kingdom, US, Japan, china, Russia and Brazil/Portugal. Jones noted that an Arabic service had been added in 2010, compiled by three young women journalists.

Jones described the work as 'a bit robotic':

(It) probably doesn't allow a lot of creativity and you are working within a fairly rigid format with a limited focus.

However, she said she personally appreciated that Headland news service 'was straight and factual news rather than the less objective sensational stories in many papers today'.

Kate Hart noted that she joined Headland as a foreign news editor providing national news for the guests:

'We have an expert for each country ... we study the websites and the key task is one of selection':

We have to have a balance between the news of the day and yet remembering that they are on holiday and we will add in lighter news. But essentially it is a mix of political and general news.

There is a difference between the national newspapers that reflects broadly the type of news/journalism in that country. Germany Today has a lot of political news, the Italian paper is generally more sensational. So while they are similar in layout each paper has its style (Hart 2010)

Hart said company stability had been an issue over the years:

We keep being acquired - most recently Sky took us over. They really wanted Betting Today to link with their sports (broadcasts) ... Then we had a 
management buyout (so) we are now on our own ... (as noted previously, KVH Industries has since acquired Headland Media)

Since that time everything about the job has changed. Software, products and markets. We need to keep looking at new media products. We produce screen products now - on-screen products, digital news for ships. Basically it's like a teletext (service) (and) we have a non-interactive cycle and an interactive one in all the different languages. (Hart 2010)

All cabins on cruise liners now had TV and dedicated channels so the Headland screen products had been integrated for these: 'We've had three evolutions on this screen product, making changes.'

Hart observed:

'We have all these new technologies but the newspaper is not dying. It is still very, very popular. We've been told there is a stampede (among passengers and crew) to collect them (at delivery time).'

When we got satellite TV available for ships we thought "that's the end" ... then when Internet became available on board for ships' passengers we thought the same.

Not everything we develop works. We developed a digest edition of the Financial Times. Because FT wouldn't let us shorten stories, this required a big reconfiguration of the software, so the layout was different. It was a difficult one to sell. Either perhaps just not the demand or perceived demand from people so the clients didn't pick it up. (Hart 2010)

Hart said the agency costs were the major input for Headland. The production software had been developed in-house and using PDF production meant there were almost no other production costs. Salaries were not discussed but this is another obvious cost input, along with physical space rental costs. Hart said:

'We've not always been secure. It's been an up-and-down ride across the years. For instance, 2001 hit us very badly. It hit the travel industry and really hit the business. (We addressed this by) the development team changing the look-andfeel (of the products) and the software. To an extent we feel our way in developments and updating.' (Hart 2010)

\section{Discussion and summary}

Significant policies enacted by $16^{\text {th }}, 18^{\text {th }}, 19^{\text {th }}$ and $20^{\text {th }}$ century governments in England, the US, and Australia indirectly but deliberately supported development of news media organisations using postal delivery subsidies as a way of ensuring sustainability of remote 
communities and of encouraging democracy and the public sphere. Research has suggested these policy initiatives were successful but that the issue of government support for news publishers remains contested, at least in Australia. Even so, there is new evidence that subsidies are being considered in Australia for news publications delivered electronically, although none for publications using PDF production.

The characteristics commonly required of news media publications to be eligible for support - a minimum number of editions per year, a minimum amount of recognisable information or news content, and standardised packaging - are clearly evident in the case study investigated, Headland Media, and the interview evidence strongly suggests these satelliteemailed editions are indeed representative of more 'regular' news periodicals.

Econometric data quantify the productivity gains available to nations which emphasise communications services for the 'people who move' market, and mobility research strongly associates mobility ('trip making') with reduced risk of social exclusion, the corollary of which is increased social capital. An average value of $\$ 17$ per trip is associated with policies which encourage trip making by people at risk of social exclusion. The combination of these factors allows the current authors to formulate a set of policy initiatives aimed at promoting media for 'people who move' as a nation-building project anywhere in the world.

\section{Conclusions}

What kind of policies? Based on the data and qualitative information presented, government subsidies should be devised and introduced to support media enterprises which promote trip making and then support 'populations on the move' or in regional and remote environments. Mechanisms for selecting such media enterprises would include identifying and characterising such populations, then identifying media technologies and news content with which to target them. The Headland Media case study strongly supports the proposition that media organisations are indeed capable of identifying discrete populations of 'people on the move', directly addressing their news needs down to a daily level using appropriate languages and localised news styles, and then using reproducible technology systems to service those news needs. As noted earlier, the potential current annual revenue for a similar business would be approximately £23.4 million, given minimal change from the 2002 and 2010 models previously examined.

Such subsidies would only be effective, however, if the infrastructure were provided for the mobile populations to receive the news products thus encouraged, and this, it is suggested, is the key condition for progressing this idea. The business model of Headland Media only works because passengers and crews on cruise liners, merchant ships, oil rigs and remote hotels are large enough to receive news bulletins while they're 'on the move' as if they are 
fixed addresses. Passengers 'on the move' in commuter trains can only receive news products if and when reception technology is on board. A key entry point for payment of subsidies to support journalism for people on the move, and consequently to enhance the social capital of populations on the move, is at the point of manufacture of devices which enable such mobile reception. The current research suggests that a subsidy should be paid to device manufacturers who also provide journalism services for mobile populations. Recommendations for enabling this are outlined below.

The introductory metaphor of the rabbit hole and the looking glass, drawn from the $18^{\text {th }}$ century works of Charles Lutwidge Dodgson (the English writer Lewis Carroll) provides some insight into what is happening here. The convergence that Jenkins $(2006,3)$ identifies - which he suggests 'represents a cultural shift as consumers are encouraged to seek out new information and make connections among dispersed media content ... (and which) occurs within the brains of individual consumers and through their social interactions with others' - is represented by the ever narrowing of the rabbit hole down to the level of the individual, and indeed the individual's brain functions. But 'through the looking glass' a new divergence is possible, where consumers are encouraged out of their rabbit holes with servings of information from familiar places ('news from home') through focused media channels (emailed PDF bulletins) which encourage social interactions with others ('We've been told there is a stampede among passengers and crew to collect them at delivery time.').

Instead of media enterprises chasing disappearing audiences with only one set of journalism products, this introduces the concept of journalists and publishers first identifying and characterising viable audiences, then addressing their news content needs with appropriate technologies. Some aspects of such an approach are hardly foreign to contemporary journalists and publishers: newspapers for train, bus and ferry commuters were commonplace historically, strengthened at the end of the $20^{\text {th }}$ century and remain popular today; radio and video services for aircraft and ferry passengers have been known for decades and continue to develop technologically (Cokley 2008, 135); news tickers on billboards beside footpaths and highways are also commonplace (Cokley 2008, 132). The new ingredient which is missing is that these journalists have written their stories first, then wondered how to sell them to the diverse mobile audiences using convergent channels. This article proposes that governments devise policies which encourage journalists to seek out and get to know the audience members first, then construct stories and use focussed channels which meet the needs of those audiences. 


\section{Recommendations}

The Australian Government can enhance the social capital of its mobile and ultra-remote populations by supporting companies:

1. Which develop, manufacture and distribute devices which are bundled with journalism software and content specifically serving mobile Australian populations; and

2. Which recruit and maintain journalists to source and provide that content.

This research highlighted one such device manufacturer/solutions provider, KVH Industries, based in the United States but which now owns Headland Media supplying journalism services and products specifically targeting and serving discrete groups of people on the move worldwide. Similar manufacturers and providers already exist in Australia and some are linked with media services. One is Pipe Networks, the fibre network and Internetexchange company recently acquired by retail Internet service provider TPG Telecom. While TPG does not specifically offer journalism products, other local ISPs do, such as Optus Zoo News (content currently provided by News Corporation) and Telstra BigPond News.

The phenomenon of ISPs owning news organisations is not new: AOL has a long history in owning and distributing journalism products, remaining in that business with the Huffington Post Media Group. Media organisations can own ISPs linked with distribution services: Foxtel and BigPond is the collaboration between News Corporation and Telstra. Organisations devoted to specific mobile populations already recruit journalists and operate targeted news enterprises: the AFL has commenced hiring journalists to support fans who come and go from their stadiums each week; Australia's automobile clubs have long maintained a sizeable network of journalists and publications, many of which (such as Queensland's Road Ahead) are created for digital delivery but just need the connectivity across the final gap to travellers. It is conceivable that news networks with existing commitments to mobile and remote populations - such as the Australian Broadcasting Corporation or the National Indigenous News Service - could acquire interests in device manufacturers or connection providers and operate this model themselves using the government support indicated in this article.

Consider a news publication designed for 'Grey Nomads', retirees who travel in caravans and campervans in developed countries such as Australia. Members of this group are increasingly equipped with basic online communications (such as iPads or iPhones) or these can be established in kiosks at van parks, are at risk of social exclusion, and have average or lower annual incomes, making them targets for policy initiatives to improve social capital (Stanley et al. 2012). The news organisation would conduct research to attract such individuals, 
identify their origin and travel patterns, news content needs and technology requirements using online preference selection boxes, then prepare targeted bulletins using email and data-light PDF bulletins.

Since even under the post-September 2013 regime, the NBN is committed only to providing infrastructure for fixed broadband services, ACMA will need to progress plans for mobile broadband to reach this discrete outlying 'Grey Nomad' population. It can do this with a model equivalent to the postal subsidies of the past. Postal subsidies assisted publishers by reducing the delivery cost per item posted based on weight because the weight of the individual item is what costs. A 'Grey Nomad' newsroom would attract a subsidy if its journalists produced sufficiently data-light products, such as the 'lite' PDFs which Headland Media editors said they try to produce. Such PDFs consume less bandwidth than data-heavy video and audio but can contain equal amounts of news, information and commentary in any language.

But the subsidy would be applied at the point of sale of the mobile broadband device, and could also be applied to an annual user subscription. For each mobile broadband + news service bundle sold, or each subscription or renewal that meets the policy requirements (and these can be 'paid' or 'free' subscriptions, depending on the level of advertising revenue from the publication) the publisher would apply to the Department of Broadband, Communications and the Digital Economy for a micro-payment comparable to discounts previously available from Australia Post. These payments would be analogous to those distributed by European governments noted earlier in this article and help support the employment of journalists to provide the desired services. In this way the government would continue its historical policy of subsidising the news delivery mechanism by the weight of the item delivered.

The market potential among 'Grey Nomads' in 2011 was 474,806 registered caravans and campervans (Caravan RV \& Accommodation Industry of Australia 2012) or nearly 1 million individual readers and viewers. It is possible to be quite specific about where this population is based and how it moves around. Most are registered in Victoria (nearly 28\%) but Queensland has recorded 36\% of the growth in registrations since 2008 and Western Australia has the highest caravan and campervan registration per 1000 people in Australia (29.8 per 1,000). Van registrations are clustered in two major hotspots, regional South-East Queensland (Bundaberg, the Fraser Coast and Toowoomba) and regional South-West Western Australia (Mandurah and Albany) (Caravan RV \& Accommodation Industry of Australia 2012).

This is also a growth industry in several different ways. Overall, registrations have grown by nearly $15 \%$ since 2008 , and the trip distance travelled by campervans alone increased by 
39\% from 2007 to 2010 (Caravan RV \& Accommodation Industry of Australia 2012). Thus a viable business plan to provide journalism services for such an audience would - using PDF bulletins delivered by satellite - offer travellers news about the two end points - regional South-East Queensland and South-West Western Australia - and along a line joining the two regions.

\section{References}

ACIL Tasman Consulting. 2008. The Value of Spatial Information, Prepared for the CRC for Spatial Information \& ANZLIC - the Spatial Information Council, Melbourne, http://crcsi.com.au/Resources, retrieved May 15, 2013

ACMA (Australian Communications and Media Authority). 2011. Towards 202O-Future spectrum requirements for mobile broadband http://www.acma.gov.au/webwr/_assets/main/lib312084/ifc13_2011_toward_2020future_spectrum_requirements.pdf, retrieved Oct 1, 2013

ACMA (Australian Communications and Media Authority) website. 2013. Your consumer rights and safeguards, http://www.acma.gov.au/Citizen/Consumer-info/My-connectedhome/The-NBN-and-you/nbn-consumer, retrieved Oct 1, 2013

Adobe website. 2013. About Adobe PDF, http://www.adobe.com/au/products/acrobat/adobepdf.html, retrieved May 13, 2013

Australia Post website. 2013. Print Post, http://auspost.com.au/parcels-mail/printpost.html, retrieved May 13, 2013

Australian Government. 2013. Budget 2013-2014: Expense Measures, Commonwealth of Australia, http://www.budget.gov.au/2013-14/content/bp2/html/bp2_expense-16.htm, retrieved May 23, 2013

Babidge, S; Cokley, J; Gordon, F; Louw, E. 2005. 'Making media work in space: an interdisciplinary perspective on media and communication requirements for current and future space communities'. International Journal of Astrobiology, 4(3-4), 259-268. http://doi.org/10.1017/S1473550405002788

Camauër, L. 2003. 'Ethnic minorities and their media in Sweden'. Nordicom Review, 24(2), 69-88.

Caravan RV \& Accommodation Industry of Australia. 2012. Caravan and Campervan Data Report 2012, Stafford Heights, Queensland.

Cokley J; with DaCosta, Aderito Hugo; Lonsdale, Jamie; Romano, Angela; Spurgeon, Christina; Tickle, Sharon. 2000. 'Media, Democracy and Development: Learning From East Timor', AsiaPacific Media Educator (\#9, July-December 2000).

Cokley J; Rankin, W.B; Söhnlein, G. 2005. 'Astronauts as audiences: characteristics of the first space communities', International Journal of Applied Aviation Studies, Vol V, No. I: pp167-182

Cokley J; Volcic, Z. 2009. Body Image Drives New Environment for News Delivery. Asia Pacific Business Review, 5(2), 49-60.

Cokley J. 2008. The Application of In Situ Digital Networks to News Reporting and Delivery, VDM Verlag Dr. Müller Aktiengesellschaft \& Co. KG, Saarbrücken, Germany

Commonwealth of Australia. 2013. Australia's Satellite Utilisation Policy, Canberra 
Fidler, Harald; Föderl-Schmid, Alexandra. 2012, 2010. Press subsidies in Austria, personal communication

Flamm, M; Kaufmann, V. 2006. Operationalising the concept of motility: a qualitative study. Mobilities, 1(2), 167-189. http://doi.org/10.1080/17450100600726563

Hart, Kate. 2010. Personal communication, Liverpool, England

Headland Media website. 2013, The Home of Welfare and Entertainment Services for Crew, http://www.headlandmedia.com/merchantships/, retrieved Oct 1, 2013

Henney, Sue. 2002. personal communication

Hoyt, George. n.d. http://www.thedigitalship.com/powerpoints/athens3/George\%2OHoyt\%2C\%2ONewsli nk.pdf, retrieved May 14, 2013

Jenkins, H. 2006. Convergence culture: Where old and new media collide. New York, NYU Press.

Jones, Bronwyn. 2010. Personal communication, Liverpool, England

Kielbowicz, Richard Burkett. 1984. News in the Mails, 169o-1863: The Technology, Policy, and Politics of a Communication Channel, University of Minnesota, PhD thesis; also published as Kielbowicz, Richard Burkett (1989) News in the Mail: The Press, Post Office, and Public Information, Greenwood Press, New York

Kielbowicz, Richard B. 2009. 'Postal Acts of 1792, 1845, 1879' in Vaughn, Stephen L. [ed] (2009) Encyclopedia of American Journalism, Routledge, New York, pp.399-401

KVH Industries website. 2013. http://www.kvh.com/About-Us.aspx, retrieved August 30, 2013

Larsen, J; Axhausen, K. W; Urry, J. 2006. Geographies of social networks: meetings, travel and communications. Mobilities, 1(2), 261-283. http://doi.org/10.1080/17450100600726654

Macnamara, J.R. 2010. 'Remodelling media: The urgent search for new media business models', Media International Australia incorporating Culture \& Policy, vol. 137, no. 11, pp. 20-35.

Milne, E. 2010. Letters, Postcards, Email: Technologies of Presence, Routledge, New York

Ots, M. 2009. 'Efficient Servants of Pluralism or Marginalized Media Policy Tools? The Case of Swedish Press Subsidies'. Journal of Communication Inquiry, 33(4), 376-392. http://doi.org/10.1177/0196859909340581

Oxera Consulting Ltd. 2013. What is the economic impact of Geo-services? Prepared for Google, Oxera Consulting, Oxford, England, http://crcsi.com.au/Resources/generalinterest/What-is-the-economic-impact-of-Geo-services-, retrieved May 15, 2013

Picard, R. G. 1985. 'Patterns of State Intervention in Western Press Economics'. Journalism Quarterly, 62(1), 3-9. http://doi.org/10.1177/107769908506200101

Rankin, W; Cokley J. 2006. 'Enhancing Life in the Hyper-Surveillance Mini-World of a Space Station: The Role of Situation Awareness, Communication, and Reality TV in the Life of Astronauts', International Journal of Applied Aviation Studies, Vol VI, No. 2, pp $283-298$

Rosen, Jay. 2006. The People Formerly Known as the Audience, June 26, 2006, http://journalism.nyu.edu/pubzone/weblogs/pressthink/2006/06/27/ppl_frmr.html, retrieved May 14, 2013 
Royal Mail website. 2013a. Publishing Mail, http://www.royalmail.com/sites/default/files/PublishingMail_ProductSummary_May20 13.pdf, retrieved May 14, 2013

Royal Mail website. 2013b. Price Guide, http://www.royalmail.com/sites/default/files/Royal_Mail_Delivery_and_Collection_Ser vices_Price_Guide_April2012.pdf, retrieved May 14, 2013

Stanley, J. K; Hensher, D. A; Stanley, J. R; Vella-Brodrick, D. 2011. Mobility, social exclusion and well-being: Exploring the links. Transportation research part A: policy and practice, 45(8), 789-801. http://doi.org/10.1016/j.tra.2011.06.007

Stanley, J; Stanley, J; Hensher, D. 2012. Mobility, Social Capital and Sense of Community: What Value? Urban Studies, 49(16), 3595-3609. http://doi.org/10.1177/0042098012447002

Thorn, William J. 2009. 'Distribution', in Sterling, Christopher H. [ed] Encyclopedia of Journalism, Sage Reference, Thousand Oaks, California, pp.425-430

United States Postal Service website. 2010. Postage Rates for Periodicals: A Narrative History, http://about.usps.com/who-we-are/postal-history/periodicals-postagehistory.htm, retrieved May 13, 2013

Winstanley, A; Cronin, K; Daly, M. 2011. 'Supporting communication around the Canterbury earthquake and other risks: A learning workshop', 7 April 2011. GNS Miscellaneous Series, 37. Retrieved May 28, 2013 from http://www.massey.ac.nz/massey/fms/Colleges/College\%20of\%20Humanities\%20and\% 20Social\%20Sciences/Psychology/Disasters/pubs/GNS/2011/Misc_Series_37_supportin g-communication.pdf

\section{Endnotes}

i Using this calculator http://www.bls.gov/data/inflation_calculator.htm, accessed August 28, 2013. The second calculator was for UK revenue, http://www.bankofengland.co.uk/education/Pages/inflation/calculator/flash/default.asp $\underline{\mathrm{x}}$

ii The Engineering Associate, Registered by Australia Post in 1984, Publication Number QBG3956

iii The original authors used the term 'motility' in their study but for consistency that has been replaced in this article with the more generally used 'mobility'

iv For instance, nearly half of the $\$ 1$ billion NASA Recovery Act 2009 funding will be spent on space exploration up to 2015, see http://www.nasa.gov/recovery/index.html, retrieved May 15, 2013

${ }^{v}$ http://headlandmedia.com/welcome/

vi Some of this background content has been published in other articles and chapters and is used with permission.

Cite this article as: Cokley, John; Comrie, Margie. 2013. 'People who move and need news. The economic and social value of providing digital journalism services for mobile and remote audiences'. Australian Journal of Telecommunications and the Digital Economy 1 (1): pp.1.1 1.22. DOI: $10.7790 / a j t d e . v 1 n 1.1 \quad$ Available at: http://telsoc.org/journal 